\title{
ASSESSMENT OF XYLANOLYTIC AND CELLULOLYTIC ACTIVITIES OF ANAEROBIC BACTERIAL COMMUNITY IN THE RUMEN OF CAMEL USING DIFFERENT LIGNOCELLULOSIC SUBSTRATES
}

\author{
A. E. Rabee ${ }^{(1)^{*}}$, A. A. S. AlAhl(2), E. A. Sabra ${ }^{(3)}$, K. Z. Kewan ${ }^{(1)}$ \\ (1) Animal and Poultry Nutrition Department, Desert Research Center, Cairo, Egypt. \\ (2) New and Renewable Energy Department, Desert Research Center, Cairo, Egypt. \\ (3) Animal Biotechnology Department, Genetic Engineering and Biotechnology Research \\ Institute, University of Sadat City, Sadat City, Egypt. \\ *Email: alaa.bakr.stu@gebri.usc.edu.eg; rabee_a_m@yahoo.com
}

Received: Feb. 17, 2019

Accepted: Mar. 24, 2019

ABSTRACTS: The microbial community in the rumen of dromedary camel is predominated by lignocellulolytic anaerobic bacteria that make the greatest contribution in the digestion of poor-quality plant biomass. Consequently, camel rumen could be a promising source of lignocellulolytic enzymes with a wide range of applications, especially in bioenergy production. However, the majority of these bacteria were not cultivated and isolated, which represent a barrier towards the exploitation of this community in enzyme production. The goal of this study was to evaluate the endocellulase and endo-xylanase production ability of anaerobic bacterial community in the rumen of the camel. For that, rumen fluid from four camels fed Egyptian clover and wheat straw were inoculated into an anaerobic rumen bacterial media containing birchwood xylan, Filter paper, Wheat straw, Alfalfa hay as a carbon source. The maximum xylanase production was $1779.05 \mathrm{mU} / \mathrm{ml}$ at 7 days of incubation. Cellulose source impacted the cellulase yield and the highest production was $1389 \mathrm{mU} / \mathrm{ml}$ for the rumen samples incubated with Alfalfa hay for 48 hours. Our findings showed that anaerobic bacterial community in the rumen of the camel is an important source of fibrolytic enzymes.

Key words: Anaerobic bacteria, Camel rumen Endo-cellulase, Endo-xylanase, In vitro.

\section{INTRODUCTION}

Plant dry weight comprises $35-50 \%$ cellulose, $20-35 \%$ hemicellulose, and 5$30 \%$ lignin (Lynd et al., 1999). Lignocellulolytic plant biomass is the most abundant renewable energy source (Whitaker, 1990; Kamble and Jadhav, 2012), and they represent the major component of agro-waste material, which is a rich and cheap source of cellulose and hemicellulose that could be converted to fermentable sugar using microbial enzymes (Kazeem et al., 2017). This process could reduce the environmental problems associated with agro-wastes and contributes to the production of clean renewable Bioenergy (bioethanol and biogas), which might reduce the concerns about the depletion of non-renewable fossil fuels and its environmental effects (Rajoka et al., 2012; Asem et al., 2017).

Cellulose has a water-insoluble crystalline structure embedded in a lignin layer. Therefore, the hydrolysis of cellulose into available biosugar is difficult (Lai et al., 2011). Lignocellulosic biomass needs to be first hydrolyzed into fermentable sugars by the synergetic work of different types of cellulases and xylanases enzymes (Fang et al., 2008; Ahmed et al., 2009; Seo et al., 2013). The cellulases family consists of three major components, endoglucanase, exoglucanase and $\beta$-glucosidase (Coughlan, 1990). While, Xylanases family is more diverse than cellulase family and consist of at least ten 
subfamilies, but the majority being endo1,4- $\beta$-xylanases (Pollet et al., 2010; Walia et al., 2017). These enzymes work synergistically to break down the cellulose and xylane in the plant cell wall ( Seo et al., 2013; Asem et al., 2017)..

Several microbial groups are involved in the production of cellulases and xylanases mainly include bacteria, fungi, yeast and protozoa (Béguin and Aubert, 1994; Chakdar et al., 2016). However, the cost of the enzyme production is the major factor for their applications in the utilization of lignocellulosic biomass (Sukumaran et al., 2005; Ibrahim et al., 2013; Chakdar et al., 2016). The cost could be reduced by utilization of cheap plant material in the enzyme production and the screening for new fibrolytic microorganisms and the innovation in the production process (Wang et al., 2012).

The gastrointestinal of ruminant animal is inhabited by a diverse microbial community consist of bacteria, protozoa, fungi and archaea (Russell and Rychlik, 2001; Yeoman and White, 2014), which ferment indigestible lignocellulosic plant material that form the major component of animal diet into nutrients used for the growth of host animal (Creevey et al., 2014). Anaerobic bacteria is the most predominant group in the microbial community in the rumen and they make the greatest contribution in the degradation of plant feedstuffs in the rumen (Henderson et al., 2015; Gharechahi et al., 2015).

The rumen microbiome is considered to be the most efficient microbial system at degrading lignocellulosic biomass (Flint et al., 2008), and some cellulolytic and xylanolytic bacterial genera were isolated from the rumen, including Rumminococcus (Ekinci et al., 2001), Bacillus (Seo et al., 2013; Sadhu et al., 2014), Clostridium (Khatab et al., 2017) and Prevotella (Avguštin et al., 1992).
Some of these isolates were involved in the commercial production of fibrolytic enzymes (Seo et al., 2013). Therefore, rumen has received a great interest for mining enzymes for biotechnological and industrial applications (Selinger et al., 1996; Hess et al., 2011; Wang et al., 2013). However, The majority of rumen microorganisms are obligate anaerobic, which represents the major challenge to exploit and understand those microbial communities (Riberio et al., 2016; Gharechahi and Salekdeh, 2018). Therfore, using Metagenomics and Metatranscriptomics technologies introduce a solution to examine and expand our understanding of the rumen microbial community (Riberio et al., 2016; Wallace et al., 2017). These techniques answer questions regarding the composition and relative abundance of microbial groups. However, these omics techniques do not address the questions regarding the metabolic activities of rumen microorganisms. Therefore, there is a need for more cultivation and physiological studies to verify predictions based on genome sequence data (Creevey et al., 2014).

Camel, like other ruminant animals depends on microbial fermentation in the rumen to degrade the ingested feedstuff (Gharechahi et al., 2015). Camels can utilize the low-quality shrubs that have a high content of lignocellulose and antinutritional factors, those plants are mostly avoided by other domestic ruminants (Iqbal et al., 2001; Samsudin et al., 2012). Consequently, camel rumen microbes must, therefore, have the capacity to degrade such poor-quality feeds (Gharechahi et al., 2015). This speculation was supported by a metagenomics analysis in camel microbiome that revealed that camel microbiome contains a higher percentage of glycoside hydrolases compared with other gastrointestinal metagenomes from other herbivorous (Bhatt et al., 2013; 
Gharechahi and Salekdeh, 2018). Consequently, camel rumen microbiota can be a source of carbohydrate-active enzymes (CAZymes), that could be used in a wide range of biotechnological and industrial applications (Ameri et al., 2018). However, Lignocellulolytic activities of camel rumen microbiome was not evaluated yet. Therefore, the objective of this study was to expand our knowledge regarding the metabolic capabilities of camel rumen microbiota by investigation the ability of anaerobic bacterial community in the rumen of the dromedary camel to produce xylanase and cellulase in vitro.

\section{MATERIAL AND METHODS \\ Rumen sample collection}

Rumen samples were collected from four adult male dromedary camels fed on Egyptian clover (Trifolium alexandrinum) and wheat straw. The samples were collected immediately after slaughtering in the Kom Hammada slaughtering house, Elbehra, Egypt. Rumen contents were strained immediately using two layers of cheese cloth to separate liquid and solid, and then liquid samples were cryopreserved using glycerol according to the protocol of Phillips and Gordon. (1988) for further processing. The project was approved and all samples were collected in accordance with the Institutional Animal Care and Use Committee, Faculty of Veterinary Medicine, University of Sadat City (Approval reference number: VUSC00008).

\section{Cultivation condition}

The enrichment media that was used in this study was the modification of Medium 10 (M10) (Caldwell and Bryant, 1966). The xylanolytic and cellulolytic activities of anaerobic bacteria of camel rumen were evaluated in replicates in four media, one xylanolytic medium (X) enriched with birchwood xylan and media enriched with one of three fiber sources, Filter Paper (FP), Wheat Straw (WS), and Alfalfa Hay $(\mathrm{AH})$ as shown in Table 1 . The pH in all media was adjusted at 6.8. Enrichment medium (20 $\mathrm{ml})$ Was prepared under anaerobic condition was dispensed in $50 \mathrm{ml}$-Serum bottles containing xylan or one of fiber sources, then the medium was sterilized by autoclaving at $121{ }^{\circ} \mathrm{C}$ for $15 \mathrm{~min}$. The samples for enzyme quantification were picked at 4 times, 24 hours (hrs.), 48 hrs,72 hrs., and 7days for cellulase and 24 hrs, 48 hrs, and 7days for xylanase. Preserved rumen samples were thawed by rapid warming in tepid water and then $0.3 \mathrm{ml}$ was inoculated to the culture medium, then the bottles were incubated at $39^{\circ} \mathrm{C}$. The growth and the presence of bacteria was confirmed using the microscopic examination and the degradation of filter paper. Furthermore, yellow pigments were observed on the filter papers.

\section{Cellulase and xylanase enzyme assay}

Enzyme assays were performed in duplicate. Samples of growing cultures were collected after $24 \mathrm{hrs}, 48 \mathrm{hrs}, 72 \mathrm{hrs}$, and 7days intervals for cellulase and 24 hrs, 48 hrs, and 7days for xylanase. The supernatant that served as the enzyme source was obtained by centrifugation of $1 \mathrm{ml}$ of bacterial cultures at (3000 rpm, 15 min, $4^{\circ} \mathrm{C}$. Cellulase and xylanase activities ( $\mathrm{mU} / \mathrm{ml}$ ) were measured using EnzChek Cellulase substrate that determines endo-1,4- $\beta$-glucanase and EnzChek Ultra Xylanase Assay Kit (Invitrogen, UK) that determines endo$1,4-\beta$-xylanase using the reaction buffer as a negative control and according to the manufacturer recommendations. These quantification methods depend on the fluorescence substrates to evaluate the enzymes activities. 
A. E. Rabee, et al.,

Table 1: The composition of anaerobic media (modification of Medium 10 (M10) (Caldwell and Bryant, 1966)) for the cultivation of cellulolytic and xylanolytic rumen bacteria.

\begin{tabular}{|c|c|c|}
\hline Ingredient & $\begin{array}{l}\text { Xylanolytic } \\
\text { Medium(X)/L }\end{array}$ & $\begin{array}{l}\text { Cellulytic } \\
\text { Medium /L }\end{array}$ \\
\hline Tryptone & $2 \mathrm{~g}$ & $2 \mathrm{~g}$ \\
\hline Yeast Extract & $0.5 \mathrm{~g}$ & $0.5 \mathrm{~g}$ \\
\hline Glucose & $0.5 \mathrm{~g}$ & - \\
\hline Maltose & $0.25 \mathrm{~g}$ & - \\
\hline Cellobiose & $0.25 \mathrm{~g}$ & $0.25 \mathrm{~g}$ \\
\hline Lactic acid $85 \%$ & $1.73 \mathrm{ml}$ & - \\
\hline Soluble Starch & $0.5 \mathrm{~g}$ & - \\
\hline Xylane & $2 \mathrm{~g}$ & - \\
\hline Mineral solution 1 & $37.5 \mathrm{ml}$ & $37.5 \mathrm{ml}$ \\
\hline Mineral solution 2 & $37.5 \mathrm{ml}$ & $37.5 \mathrm{ml}$ \\
\hline Resazurin $0.1 \%$ & $1 \mathrm{ml}$ & $1 \mathrm{ml}$ \\
\hline VFA solution & $4.5 \mathrm{ml}$ & $4.5 \mathrm{ml}$ \\
\hline Vitamins Solution & $5 \mathrm{ml}$ & $5 \mathrm{ml}$ \\
\hline $\mathrm{FeSO}_{4}$ solution & $5 \mathrm{ml}$ & $5 \mathrm{ml}$ \\
\hline Hemin Solution $\mathbf{0 . 2 \%}$ & $5 \mathrm{ml}$ & $5 \mathrm{ml}$ \\
\hline $\mathrm{Na}_{2} \mathrm{Co} 38 \%$ & $50 \mathrm{ml}$ & $50 \mathrm{ml}$ \\
\hline Cys. HCL 2.5\% & $20 \mathrm{ml}$ & $20 \mathrm{ml}$ \\
\hline water & $630 \mathrm{ml}$ & $630 \mathrm{ml}$ \\
\hline Clarified rumen fluid & $200 \mathrm{ml}$ & $200 \mathrm{ml}$ \\
\hline \multicolumn{3}{|c|}{ Cellulose Source for cellulytic Media } \\
\hline Filter paper (FP) & - & 2 disc / bottle \\
\hline Wheat Straw (WS) & - & $50-100 \mathrm{mg} /$ bottle \\
\hline Alfalfa Hay (AH) & - & $50-100 \mathrm{mg} /$ bottle \\
\hline
\end{tabular}

VFA:Volatile Fatty Acid; FeSo $4:$ Ferrous sulfate; $\mathrm{Na}_{2} \mathrm{Co}_{3}$ : Sodium carbonate; Cys. HCL: L-Cysteine hydrochloride.

\section{Statistical analysis}

The statistical analyses were performed using the IBM SPSS version 20 software (SPSS, 1999). The difference in xylanase production at different incubation times was performed using Repeated Measures ANOVA and the difference was statistically different at $P$ $<0.05$. The differences in cellulase production using different cellulose sources and the production at different incubation time and the interaction between incubation time and cellulose sources were performed using Mixed ANOVA and the difference was statistically different at $P<0.05$. A post hoc Tukey test was carried out to determine the significant differences. 


\section{Results}

The current study is a preliminary study to assess the ability of anaerobic bacteria in rumen of dromedary camel to produce bacterial cellulase and xylanase (in vitro) using rumen samples from dromedary camel fed Egyptian clover and wheat straw. The rumen samples were inoculated to anaerobic bacterial media enriched with xylane and different sources of cellulose to examine the effect of cellulose source on cellulase production. Moreover, the effect of incubation time on xylanase and cellulase production was also tested.

\section{Xylanase production}

Optimizing xylanase production at different incubation type is important, the bacterial xylanase (endo-1,4- $\beta$ - xylanase) production was evaluated by incubating camel rumen samples in anaerobic bacterial medium containing birch wood xylane at a range of incubation time 24 $\mathrm{hrs}, 48 \mathrm{hrs}$ and 7 days at $38^{\circ} \mathrm{C}$ and $\mathrm{pH}=6.8$ (Figure 1). The analysis of xylanase production showed that the xylanase was raised gradually and reached maximum activity at 7 days. The overall mean production was $124.5 \pm 37.6 \mathrm{mU} / \mathrm{ml}$ (mean \pm sd) at $24 \mathrm{hrs}, 315.3 \pm 113.4$ at $48 \mathrm{hrs}$, and $1779.05 \pm 102.9$ at 7 days. The difference in xylanase production at different incubation times was significant $(P<0.01)$ (Figure 1).

\section{Cellulase production at different incubation times and using different cellulose sources}

Bacterial cellulase (endo-1,4- $\beta$ glucanase) production was evaluated by incubating camel rumen samples in anaerobic bacterial media containing one of three different sources of cellulose, Filter Paper (FP), Wheat Straw (WS) and
Alfalfa Hay (AH) at different incubation times $24 \mathrm{hrs}, \mathbf{4 8} \mathrm{hrs}, \mathbf{7 2} \mathrm{hrs}$ and 7 days at $38^{\circ} \mathrm{C}$ and $\mathrm{pH}=6.8$ to optimize the enzyme production. The results indicated that the production of cellulase was changed with increasing the incubation time and was dependent on the cellulose type. The production in FP media was raised slowly by increasing incubation time and the highest production was observed at 7 days (Table 2). A similar trend was observed in WS media; however, the production declined at $72 \mathrm{~h}$ then increased and the highest production was observed at 7 days. The highest cellulase production in $\mathrm{AH}$ media was registered at $48 \mathrm{hrs}$ then decreased (Table 2). The Tuckey test showed that the difference in cellulase production between cellulose sources was significant $(P<0.01)$, the difference was significant between $A H$ to WS and FP. Furthermore, the difference in cellulase production at different incubation time ( $P$ $<0.01$ ).

A comparison of cellulase production of the anaerobic bacterial community using different cellulose sources at 48 hrs and 7 dayas revealed that the cellulase yield was increased by approximately 37-fold from $48 \mathrm{hrs}$ to 7days in FP media. While the yield increased by $42.95 \%$ from $48 \mathrm{hrs}$ to 7 days in WS media. In contrast, the cellulase yield was decreased by $43.5 \%$ from 48 hrs to 7 days in AH media (Figure 2). These results showed that the highest cellulase production in the current study was observed with anaerobic bacterial media inoculated with Alfalfa hay at $\mathbf{4 8}$ hrs. In addition, the wheat straw media could be effective in cellulase production at $48 \mathrm{hrs}$. The interaction between time and substrate was significant $(P<0.01)$. 


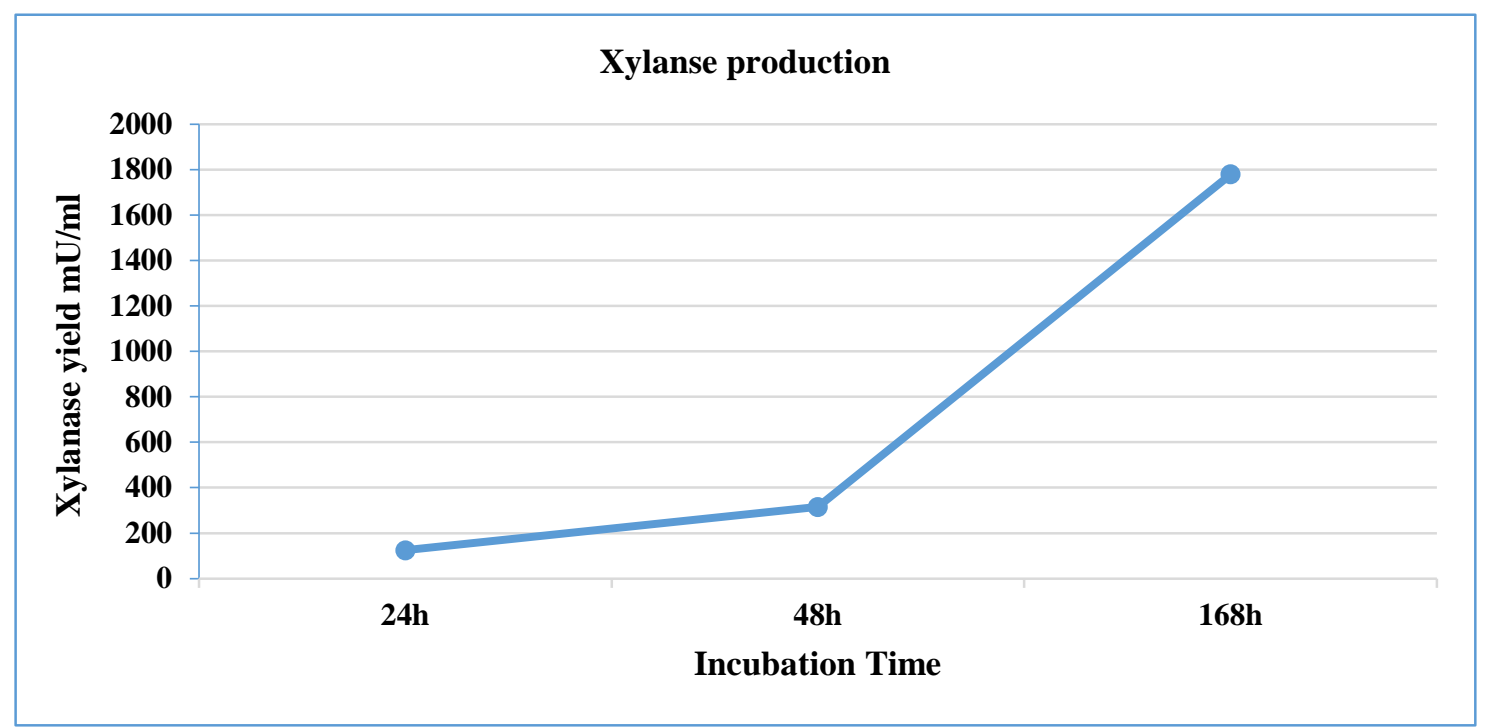

Figure 1: Effect of incubation time on endo-xylanase activity $(\mathrm{mU} / \mathrm{ml})$ of anaerobic bacterial community in the rumen of dromedary camel.

Table 2: Effect of different cellulose source and incubation times on endo-cellulase activity $(\mathrm{mU} / \mathrm{ml})$ (mean $\pm \mathrm{SD}$ ) of bacterial community in the rumen of dromedary camel.

\begin{tabular}{|l|c|c|c|c|}
\hline \multirow{2}{*}{ Cellulose Source } & \multicolumn{4}{|c|}{ Incubation Times } \\
\cline { 2 - 5 } & 24 hours & 48 hours & 72 hours & 7 days \\
\hline Filter Paper (FP) & $20.8 \pm 3.2$ & $21.1 \pm 2.8$ & $49.4 \pm 19.1$ & $799.2 \pm 452.9$ \\
\hline Wheat Straw (WS) & $48.7 \pm 33$ & $422.8 \pm 87.9$ & $193.5 \pm 35.3$ & $604.4 \pm 122.23$ \\
\hline Alfalfa Hay (AH) & $47.85 \pm 3.8$ & $1389 \pm 350.7$ & $959.9 \pm 470$ & $784.7 \pm 418.1$ \\
\hline
\end{tabular}

Cellulase production at $48 \mathrm{hrs}$ :

1600

1400

1200

1000

흘 800

600

Figure 2: A comparison of endo-cellulase activity $(\mathrm{mU} / \mathrm{ml})$ of anaerobic bacterial community in the rumen of dromedary camel using different carbon substrates at $48 \mathrm{hrs}$ and 7 days. 


\section{Discussion}

Camel rumen is a rich source of lignocellulolytic enzymes and different microorganisms producing them, thus it represents a good source of enzymes and productive bacteria for different biotechnological purposes (Zorec et al., 2014; Ameri et al., 2018; Gharechahi and Salekdeh, 2018). Metagenomic analysis of camel rumen bacteria suggested that the camel rumen metagenome is enriched for genes involved in cellulose and xylan degradation more than other ruminant animals; in addition, genes encoding endoglucanases and endoxylanases were over-represented in the camel rumen's metagenome (Gharechahi and Salekdeh, 2018). However, only a small proportion of rumen bacteria were isolated, which represent a barrier towards the exploitation of this community in enzymes production (Creevey et al., 2014; Nyonyo et al., 2014). This work demonstrates the possibility of production of cellulase and xylanase using camel rumen contents inoculated to anaerobic bacterial media enriched with xylane and different fiber sources, including filter paper, wheat straw and alfalfa hay.

\section{Xylanolytic activities}

Xylanase production in the current study increased continuously by increasing the incubation time and reached the maximum at 7 days (Figure 1), this finding had a similar trend to results on different xylanolytic gut bacteria (Asem et al., 2017). However, the xylanase production in the present study was lower than the production of Bacillus isolated from the rumen of the Korean goat (Seo et al., 2013). On the other hand, the anaerobic bacterial community in this study produced more xylanase than the aerobic fungi (Salmon et al., 2014) and anaerobic rumen fungi of camel gut
(Rabee et al., 2018). Xylanase in this study was quantified as endo-1,4- $\beta$ xylanase attacks 1,4-linkages, which represents the major component of xylanases family. Moreover, it has a greater catalytic versatility and can catalyze the hydrolysis of even cellulose and cellobios (Pollet et al., 2010).

\section{Cellulolytic activities}

In this study, the cellulase activity was examined at different times, the result revealed that cellulase production varied by increasing the incubation time and the production reached the optimum at 7 days in media containing FP or WS (Table 2). Unlikely, the cellulase production in $\mathrm{AH}$ media reached the maximum at $48 \mathrm{hrs}$ and decreased sharply. This results in the same line with the results of cellulolytic bacteria isolated from goat and swine (Seo et al., 2013; Yang et al., 2014; Asem et al., 2017), and cow manure (Sadhu et al., 2014).

\section{Effect of carbone source on cellulase yield}

The activities of fibrolytic enzymes are strongly influenced by the growth substrate (William and Withers, 1982; Ekinci et al., 2001). In the present study, different sources of cellulose were examined to explore their impact on cellulase yield. The result revealed that maximum production was obtained with media containing alfalfa hay $(\mathrm{AH})$ at $\mathbf{4 8}$ hrs followed by media containing filter paper (FP) at 7d (Table 2). Therefore, the alfalfa hay could be used to produce cellulase from anaerobic rumen bacteria. Cellulase production in the current study was higher than cellulase production of Bacillus isolated from cow dung (Sadhu et al., 2014) and other cellulolytic bacteria isolated from goat and swine (Asem et al., 2017). Furthermore, it was higher than aerobic fungi (Salmon et al., 2014) and 
anaerobic rumen fungi in camel rumen that were incubated in alfalfa hay (Rabee et al., 2018).

Our findings highlight the anaerobic bacterial community in camel rumen as a promising source for cellulase and xylanase to meet the global demand for these enzymes, as most of the commercial lignocellulolytic enzymes are being produced by fungi, which have a slower growth rate and longer fermentation period than bacteria. Consequently, the cost of production is high (Westers et al., 2004; Yang et al., 2014; Maki et al., 2011; Ladeira et al., 2015; Gaur et al., 2015). On the other hand, the anaerobic bacterial community in the current study has been cultivated with cheap and available sources of cellulose (wheat straw and Alfalfa hay). Wheat straw exhibited a good cellulase production at $48 \mathrm{hrs}(422.8 \mathrm{mU} / \mathrm{ml})$ comparing with the production at 7 days $(604.4 \mathrm{mU} / \mathrm{ml})$, this indicated that wheat straw also could be recommended for the production at $\mathbf{4 8} \mathrm{hrs}$, and that might save the time and the cost of production compared with FP media (Figure 2). Using cheap substrates for cellulase production is recommended to save the cost of production (Wang et al., 2012).

Higher cellulase yield in $\mathrm{AH}$ medium could be attributed to the lower lignin content in Alfalfa compared to wheat straw (Martin and Mertens, 2005; Shrivastava et al., 2014). Lignin restricts the microbial degradation of plant cell wall carbohydrates (Shrivastava et al., 2014). Furthermore, the fiber in Alfalfa has a higher digestion rate than grass fiber (Martin and Mertens, 2005), which might increase the bacterial count (Chung and Hungate, 1976). Hespell and Argyle. (1987) investigated the digestion of alfalfa hay by anaerobic rumen bacteria in vitro, and they noticed that glucose started to disappear after $12 \mathrm{hrs}$ and was completely gone by $48 \mathrm{hrs,}$ hemicellulose and cellulose digestion began after $12 \mathrm{hrs}$, these findings could illustrate the results of our study. The decrease in production in AH after $48 \mathrm{hrs}$ could be explained as a result of the excessive consumption of nutritional ingredients in the medium (Yang et al., 2014). Endo-Cellulase hydrolyzes cellulose by cutting the internal amorphous sites and soluble derivatives of the cellulose molecule, which produce oligosaccharides of different lengths (Kuhad et al., 2011; Fariq, 2016).

\section{Lignocellulolytic bacteria in camel rumen}

Previous studies on microbial community in camel rumen revealed that the bacterial community in the rumen of the camel is largely dominated by cellulolytic and xylanolytic bacterial genera that include Fibrobacter, Butyrivibrio, Clostridium, Ruminococcus, Treponema, Bacilli, and Prevotella (Samsudin et al., 2011; Samsudin et al., 2012; Gharechahi et al., 2015). These genera are the major contributors to lignocellulose degradation in the rumen (Gharechahi and Salekdeh, 2018). Camel has the ability to retain ingested material in the rumen for a longer time than other ruminant and the $\mathrm{pH}$ in camel rumen is closer to neutral, which support colonization of cellulolytic bacteria and the efficient degradation of fibrous diets (Stevens and Hume, 1998; Jouany, 2000; Samsudin et al., 2011).

The high proportion of cellulolytic and hemicellulolytic bacteria in the rumen of camel reflects the ability of camel to utilize the abundance of low-quality shrubs and poor quality forages, which are mostly avoided by domestic ruminants (Iqbal and Khan et al., 2001; Gharechahi et al., 2015; Gharechahi and Salekdeh, 2018). Samsudin et al. (2012) used rumen content from dromedary camels to inoculate three different enrichment media contain different fiber 
sources, including cotton thread, filter paper, and neutral detergent fiber from lucerne hay, the results showed that the fiber type influenced bacterial species that grow in the fiber-enriched medium. Moreover, members related to the phylum Firmicutes were dominant and some of the bacteria involved in fiber digestion were assigned to Fibrobacters. In another study by Gharechahi and Salekdeh. (2018), the metagenomics analysis of camel rumen microbiota revealed that species related to phylum Firmicutes and Fibrobacteres were rich in cellulases and hemicellulases lineages that have a possible role in the degradation of lignocellulose. These findings explain that the variation in cellulase yield among the substrates in the current study could be attributed to the variation in the composition of bacterial community associated with the carbon sources. In the current study, the partially degraded filter papers showed a yellow pigment, which indicates to the presence of Ruminococcus that produce cellulase and xylanase (Ekinci et al., 2001).

All the previous speculations confirm that camel rumen is a promising source of cellulolytic and xylanolytic enzymes and bacteria that could be used in a wide range of applications in many fields. However, more studies are recommended to isolate cellulolytic and xylanolytic bacteria from camel rumen and to make more production optimizations under different cellulolytic and xylanolytic substrates, $\mathrm{pH}$ and temperatures. Xylanases and cellulases have numerous applications worldwide; for example, it is used for biobleaching of pulps in the paper industry, brewing, laundry detergents and in backing industry. Furthermore, it can be included in animal feed additives, probiotics, and biofuel production; also, it can be involved in the recycling of waste paper (Kuhad et al., 2011; Fariq, 2016; Chakdar et al., 2016). In this study, we quantified the cellulase and xylanase using Fluorescence substrates that enable the highly sensitive detection of xylanolytic and cellulolytic activities and allow to the differentiation between exo and endo activities (Helbert et al. 2003; Khatri et al. 2016).

\section{Conclusion}

It can be concluded that the rumen fluid of the dromedary camel is a promising source of lignocellulolytic enzymes that could be used in a wide range of applications. The incubation time has an impact in cellulase and xylanase yield. In addition, the cellulose source influenced the cellulase production, where Alflalfa hay supported the highest cellulase production, which offer the possibility to reduce the cost of cellulase production using cheap cellulos sources.

\section{REFERENCES}

Ameri, R., E. Laville, G. PotockiVeÂronèse, $S$. Trabelsi, M. Mezghani, F. Elgharbi and S. Bejar (2018). Two new gene clusters involved in the degradation of plant cell wall from the fecal microbiota of Tunisian dromedary. PLoS ONE, 13: e0194621. https://doi.org/10.1371/journal.pone.01 94621.

Asem, D., V. V. Leo, A. K. Passari, M. V. Tonsing, J. B. Joshi and S. Uthandi et al. (2017). Evaluation of gastrointestinal bacterial population for the production of holocellulose enzymes for biomass deconstruction. PLoS ONE, 12: e0186355. https://doi.org/10.1371/journal.pone.01 86355.

Avguštin, G., H. J. Flint and T. R. Whitehead (1992). Distribution of xylanase genes and enzymes among strains of Prevotella (Bacteroides) ruminicola from the rumen. FEMS Microbiol Lett, 99: 137-144. 
Bhatt, V. D., S. S. Dande, N. V. Patil and C. G. Joshi (2013). Molecular analysis of the bacterial microbiome in the forestomach fluid from the dromedary camel (Camelus dromedarius). Mol Biol Rep, 40: 3363 \pm 71 . https://doi.org/10.1007/s11033-0122411-4.

Béguin, P. and J. P. Aubert (1994). The biological degradation of cellulose. FEMS Microbiol Rev, 13:25-58. http://dx.doi.org/10.1016/01686445(94)90099-X.

Caldwell, D. R. and M. P. Bryant (1966). Medium without rumen fluid for nonselective enumeration and isolation of rumen bacteria. Appl Microbiol. 14: 794-801.

Chakdar, H., M. Kumar, K. Pandiyan, A. Singh, K. Nanjappan, P. L. Kashyap and A. K. Srivastava (2016). Bacterial xylanases: biology to biotechnology. 3 Biotech, 6:150. DOI 10.1007/s13205016-0457-z.

Chung, K. T. and R. E. Hungate (1976). Effect of alfalfa fiber substrate on culture counts of rumen bacteria. Appl Environ Microbiol, 32: 649-652.

Coughlan, M. P. (1990). Cellulose degradation by fungi. Enzyme Microb Technol 2nd ed. Springer 1-36.

Creevey, C. J., W. J. Kelly, G. Henderson and S. C. Leahy (2014). Determining the culturability of the rumen bacterial microbiome. Microb Biotechnol, 7:467-479. doi:10.1111/17517915.12141.

Ekinci, M. S., N. Özcan, E. ÖzkÖse and H. J. Flint (2001). A Study on cellulolytic and hemicellulolytic enzymes of anaerobic rumen bacterium Ruminococcus flavefaciens Strain 17. Turk J Vet Anim Sci, 25: 703-709.

Fariq, A. (2016). Microbial cellulases: production and Application. Journal of Biotechnology Science Research, 3: 122-127.

http://issres.net/jbsr/pubsystem/index. php/jbsr/article/view/33/66.
Flint, H. J., E. A. Bayer, M. T. Rincon, R. Lamed and B. A. White (2008). Polysaccharide utilization by gut bacteria: Potential for new insights from genomic analysis. Nat Rev Microbiol, 6:121-131. doi:10.1038/nrmicro1817.

Gaur, R. and S. Tiwari (2015). Isolation, production, purification and characterization of an organic-solvent thermostable alkalophilic cellulase from Bacillus vallismortis RG-07. BMC Biotechnol, 15:19. DOI 10.1186/s12896-015-0129-9.

Gharechahi, J., H. S. Zahiri, K. A. Noghabi and G. H. Salekdeh (2015). In-depth diversity analysis of the bacterial community resident in the camel rumen. Syst Appl Microbiol, 5:67-76. doi: 10.1016/j.syapm.2014.09.004.

Gharechahi, J. and G. H. Salekdeh (2018). A metagenomic analysis of the camel rumen's microbiome identifies the major microbes responsible for lignocellulose degradation and fermentation. Biotechnol Biofuels, 11:216. https://doi.org/10.1186/s13068018-1214-9.

Halliwell, G. and M. P. Bryant (1963). The cellulolytic activity of pure strains of bacteria from the rumen of cattle. J Gen Microbiol, 32:441- 448.

Helbert, W., H. Chanzy, T.L. Husum, M. Schülein and S. Ernst (2003). Fluorescent cellulose microfibrils as substrate for the detection of cellulase activity. Biomacromolecules, 4:481487. DOI: 10.1021/bm020076i.

Henderson, G., F. Cox, S. Ganesh, A. Jonker, W. Young, Global Rumen Census Collaborators. and P. J. Janssen (2015). Rumen microbial community composition varies with diet and host, but a core microbiome is found across a wide geographical range. Sci Rep, 5:14567. doi:10.1038/srep14567.

Hess, M., A. Sczyrba, R. Egan, T. W. Kim, H. Chokhawala, G. Schroth, S. Luo, D. 
S. Clark, F. Chen, T. Zhang, R. I. Mackie, L. A. Pennacchio, S. G. Tringe, A. Visel, T. Woyke, Z. Wang and E. M. Rubin (2011). Metagenomic discovery of biomass degrading genes and genomes from cow rumen. Science, 331:463-467.

doi:

10.1126/science. 1200387.

Hespell, R. B. and J. L. Argyle (1987). Digestion of alfalfa hay using washed ruminal bacteria. J Dairy Sci, 70:25252533.

Ibrahim, M., M. Razak, L. Phang, M. Hassan and S. Abd-Aziz (2013). Crude cellulase from oil palm empty fruit bunch by Trichoderma asperellum UPM1 and Aspergillus fumigatus UPM2 for fermentable sugars production. Appl Biochem Biotechnol, 170: 1320-1335. doi: 10.1007/s12010013-0275-2.

Iqbal, A. and B. B. Khan (2001). Feeding behaviour of camel. Pak J Agric Sci, 38:58-63.

Jouany, J. P. (2000). The digestion in camelids: a comparison to ruminants. INRA Prod Anim, 13: 165-176.

Kamble, R. D. and A. R. Jadhav (2012). Isolation, purification, and characterization of xylanase produced by a new species of Bacillus in solid state fermentation. Int J Microbiol, 683193. doi:10.1155/2012/683193.

Kazeem, M. O., U. K. Shah, A. S. Baharuddin and N. A. AbdulRahman (2017). Prospecting agro-waste cocktail: supplementation for cellulase production by a newly isolated thermophilic. Appl Biochem Biotechnol, 182:1318-1340. DOI 10.1007/s12010-017-2401-z.

Khatab, M. S. A., A. M. Abd El Tawab and M. T. Fouad (2017). Isolation and characterization of anaerobic bacteria from frozen rumen liquid and its potential characterization. Int $\mathbf{J}$ Dairy Sci, 12:47-51. DOI: 10.3923/ijds.2017.47.51.
Khatri, V., Y. Hebert-Ouellet, F. MeddebMouelhi and M. Beauregard (2016). Specific tracking of xylan using fluorescent-tagged carbohydrate-binding module 15 as molecular probe. Biotechnol Biofuels, 9:74. DOI 10.1186/s13068-016-0486-1.

Kuhad, R. C., R. Gupta and A. Singh (2011). Microbial cellulases and their industrial applications.

Enzyme $\quad 280696$. doi:10.4061/2011/280696.

Ladeira, S. A., E. Cruz, A. B. Delatorre, J. B. Barbosa and M. L. L. Martins (2015). Cellulase production by thermophilic Bacillus sp. SMIA-2 and its detergent compatibility. Electron J Biotechnol, 18:110-115.

https://doi.org/10.1016/j.ejbt.2014.12.0 08.

Lai, D., L. Deng, J. Li, B. Liao, Q. X. Guo and Y. Fu (2011). Hydrolysis of cellulose into glucose by magnetic solid acid. Chem Sus Chem, 4:55-8. http://dx.doi.org/10.1002/cssc.2010003 00.

Lynd, L. R., C. E. Wyman and T. U. Gerngross (1999). Biocommodity engineering. Biotechnol Prog, 15:77793.

http://dx.doi.org/10.1021/bp990109e.

Maki, M. L., M. Broere, K. T. Leung and W. Qin (2011). Characterization of some efficient cellulase producing bacteria isolated from paper mill sludges and organic fertilizers. Int J Biochem Mol Biol, 2:146-154.

Martin, N. P., D. R. Mertens (2005). Reinventing alfalfa for dairy cattle and novel uses In: Proceedings, California Alfalfa and Forage Symposium, Visalia, CA, UC Cooperative Extension, Agronomy Research and Extension Center, Plant Sciences Department, University of California.

Nyonyo, T., T. Shinkai and M. Mitsumori (2014). Improved culturability of cellulolytic rumen bacteria and phylogenetic diversity of culturable 
cellulolytic and xylanolytic bacteria newly isolated from the bovine rumen. FEMS Microbiol Ecol, 88:528-537. DOI: 10.1111/1574-6941.12318.

Rabee, A. E., R. J. Forster and C. 0. Elekwachi et al. (2018). Community structure and fibrolytic activities of anaerobic rumen fungi in dromedary camels. J Basic Microbiol:1-10. https://doi.org/10.1002/jobm.20180032 3.

Rajoka, M. I., S. Ahmed, A. S. Hashmi and M. Athar (2012). Production of microbial biomass protein from mixed substrates by sequential culture fermentation of Candida utilis and Brevibacterium lactofermentum. Annals Microbiol, 62:1173-1179. https://doi.org/10.1007/s13213-0110357-8.

Phillips, M. W. and G. L. R. Gordon (1988). Sugar and polysaccharide fermentation by rumen anaerobic fungi from Australia, Britain and New Zealand. BioSystems, 21:377-83.

Pollet, A., J. A. Delcour and C. M. Courtin (2010). Structural determinants of the substrate specificities of xylanases from different glycoside hydrolase families. Crit Rev Biotechnol, 30:176191. doi: 10.3109/07388551003645599.

Ribeiro, G. O., R. J. Gruninger, A. Badhan and T. A. McAllister (2016). Mining the rumen for fibrolytic feed Enzymes. Animal Front, 6:20-26. doi:10.2527/af.2016-0019.

Russell, J. B. and J. L. Rychlik (2001). Factors that alter rumen microbial ecology. Science, 292:1119-1122. doi:10.1126/science.1058830.

Sadhu, S., P. K. Ghosh, G. Aditya and T. K. Maiti (2014). Optimization and strain improvement by mutation for enhanced cellulase production by Bacillus sp. (MTCC10046) isolated from cow dung. Journal of King Saud University - Science, 26:323-332. http://dx.doi.org/10.1016/j.jksus.2014.0 6.001.
Salmon, D. N. X., M. R. Spier, C. R. Soccol, L. P. S. Vandenberghe, V. W. Montibeller, M. C. J. Bier and V. Faraco (2014). Analysis of inducers of xylanase and cellulase activities production by Ganoderma applanatum LPB MR-56. Fungal Biol, 118:655-662. http://dx.doi.org/10.1016/j.funbio.2014. 04.0.

Samsudin, A. A., P. N. Evans, A. D. Wright and R. Al Jassim (2011). Molecular diversity of the foregut bacteria community in the dromedary camel (Camelus dromedarius). Environ Microbiol, 13:3024-3035. doi: 10.1111/j.1462-2920.2011.02579.x.

Samsudin, A. A., A-D. G. Wright and R. Al Jassim (2012). Cellulolytic bacteria in the foregut of the dromedary camel (Camelus dromedarius). Appl Environ Microbiol, 78: 8836-8839. https://doi.org/10.1128/AEM.02420-12.

Selinger, L. B., C. W. Fosberg and K. J. Cheng (1996). The rumen: $A$ unique source of enzymes for enhancing livestock production. Anaerobe, 2:263-284. doi:10.1006/anae.1996.0036.

Seo, J. K., T. S. Park, I. H. Kwon, M. Y. Piao, C. H. Lee and J. K. Ha (2013). Characterization of cellulolytic and xylanolytic enzymes of Bacillus licheniformis JK7 isolated from the rumen of a native Korean goat. AsianAust J Anim Sci, 26:50-58. doi: 10.5713/ajas.2012.12506.

Shrivastava, B., K. K. Jain, A. Kalra and R. C. kuhad (2014). Bioprocessing of wheat straw into nutritionally rich and digested cattle feed. Sci Rep, 4: 6360. doi: 10.1038/srep06360.

SPSS. (1999). Statistical Package for Social Science "Release 15, SPSS INC, Chicago. USA.

Stevens, C. E. and I. D. Hume (1998). Contributions of microbes in vertebrate gastrointestinal tract to production and conservation of nutrients. Physiol Rev, 78:393-427. 
Sukumaran, R. K., R. R. Singhania and A. Pandey (2005). Microbial cellulasesproduction, applications and challenges. J Sci Ind Res, 64:832. http://hdl.handle.net/123456789/5375.

Walia, A., S. Guleria, P. Mehta, A. Chauhan and J. Parkash (2017). Microbial xylanases and their industrial application in pulp and paper biobleaching: a review. 3 Biotech, 7:11. DOI 10.1007/s13205-0160584-6.

Wallace, R. J., T. J. Snelling, C. A. McCartney, I. Tapio and F. Strozzi (2017). Application of meta-omics techniques to understand greenhouse gas emissions originating from ruminal metabolism. Genet Sel Evol ,49:9. DOI 10.1186/s12711-017-0285-6.

Wang, T., Y. Zhang, H. Yu and F. Wang (2012). Advanced manufacturing technology in China: a roadmap to 2050. Berlin: Springer.

Wang, L., A. Hatem, U. V. Catalyurek, M. Morrison and Z. Yu (2013). Metagenomic insights into the carbohydrate-active enzymes carried by the microorganisms adhering to solid digesta in the rumen of cows. PLoS ONE, 11:e78507. doi:10.1371/journal.pone.0078507.

Westers, L., H. Westers and W. J. Quax (2004). Bacillus subtilis as cell factory for pharmaceutical proteins: A biotechnological approach to optimize the host organism. Biochim Biophys
Acta Mol Cell Res, 1694:299-310. http://dx.doi.org/10.1016/j.bbamcr.200 4.02.011.

Whitaker, J. R. (1990). New and future uses of enzymes in food processing. Food Biotechnol, 4:669-97. http://dx.doi.org/10.1080/08905439009 549782.

Williams, A. G. and S. E. Withers (1982). The production of plant cell wall polysaccharide-degrading enzymes by hemicellulolytic rumen bacterial isolates grown on a range of carbohydrate substrates. J. Appl. Bacteriol, 52: 377-387.

Yang, W., F. Meng, J. Peng, P. Han, F. Fang, L. Ma and B. Cao (2014). Isolation and identification of a cellulolytic bacterium from the Tibetan pig's intestine and investigation of its cellulase production. Electron J Biotechnol, 17:262-267. https://doi.org/10.1016/j.ejbt.2014.08.0 02.

Yeoman, C. J. and B. A. White (2014). Gastrointestinal tract microbiota and probiotics in production animals. Annu Rev Anim Biosci, 2:469-86. doi: 10.1146/annurev-animal-022513114149.

Zorec, M., M. Vodovnik, R. MarinŠekLogar (2014). Potential of Selected Rumen Bacteria for Cellulose and Hemicellulose Degradation. Food Technol Biotechnol, 52:210-221. https://hrcak.srce.hr/122346. 


\section{تقييم الانشطة الهاضمة للسليولوز والزيلان للبكتريا اللاهوائية فى كرش الابل باستخدام مصادر لجنوسليولوز مختلفة}

علاء ربيع(')، عمرو سيد الاهل()، إبراهيم عبد المحسن صبره(")، خالد كيوان(') (1) قسم تغذية الحيوان والدواجن - مركز بحوث الصحراء

(") قسم الطاقة الجديدة والمتجددة - مركز بحوث الصحراء (r) قسم البيوتكنولوجيا الحيوانية - معهد الهندسة الوراثية والتكنولوجيا الحيوية - جامعة مدينة السادات الملخص العربى المعتئ

المجتمع الميكروبى بكرش الابل العبى يسوده البكتريا اللاهوائية الهاضمة للمواد اللجنوسليولوزية والتى تساهم

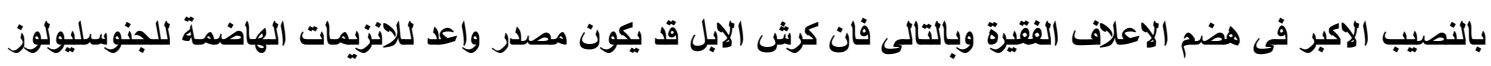

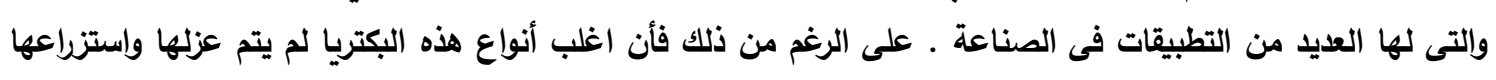

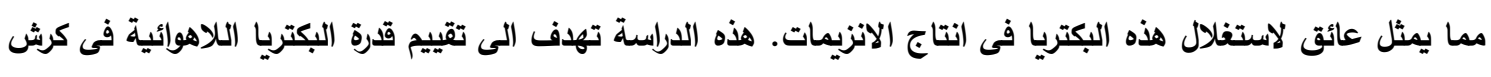

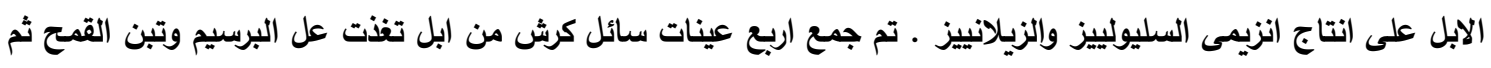

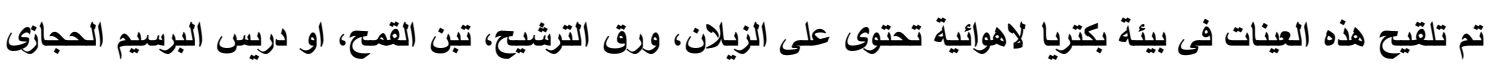

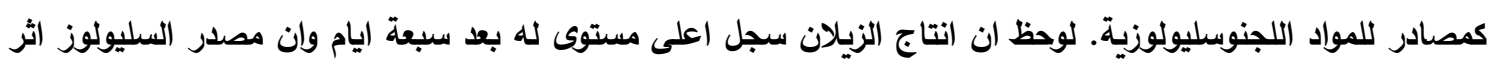

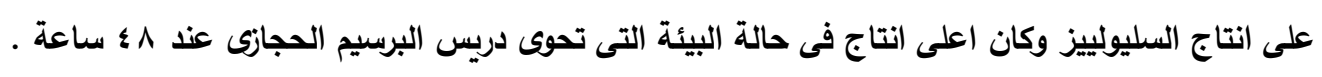

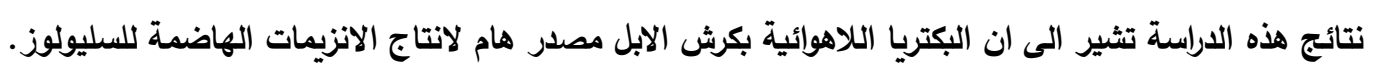


